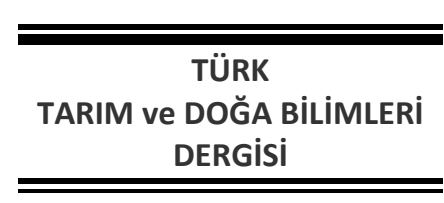

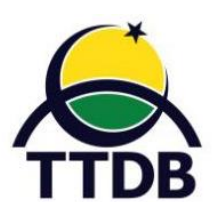

www.dergipark.gov.tr/turkjans Research Article
TURKISH

JOURNAL Of AGRICULTURAL and NATURAL SCIENCES

\title{
Comparison of the Morphometric Characteristics of Some Species of the Genus Microtus Schrank, 1798 (Mammalia: Rodentia) in the Central Anatolia Region of Turkey
}

\author{
Serdar GÖZÜTOK ${ }^{1 *}$, İrfan ALBAYRAK ${ }^{2}$ \\ ${ }^{1}$ Department of Wildlife Ecology and Management, Faculty of Agricultural and Natural Sciences, University of \\ Bolu Abant İzzet Baysal, Gölköy Campus, 14030, Bolu, Turkey \\ ${ }^{2}$ Department of Biology, Faculty of Science and Arts, University of Kırıkkale, 71450, Yahşihan, Kırıkkale, Turkey \\ *Corresponding Author: serdargozutok@ibu.edu.tr
}

Received: 19.05.2020 Revised in Received: 11.06.2020 Accepted: 12.06 .2020

\begin{abstract}
The aim of this study was to determine and compare some morphometric characteristics of Microtus species occurring in the central Anatolia, Turkey. This study is based on 209 specimens of Microtus spp. collected the central Anatolia between 2003 and 2010. Some features concerning pelage coloration, cranial characters, tooth morphotype, and baculum morphology of the species were recorded to determine and evaluate their taxonomic characteristics. It was determined that four species of the genus Microtus occur in the study area, including Microtus dogramacii, Microtus guentheri, Microtus hartingi, and Microtus mystacinus. Microtus hartingi has been found to be widespread throughout central Anatolia. Microtus guentheri is located in the type locality and nearby provinces. M. guentheri and $M$. hartingi were not found to be sympatric. Among species, $M$. hartingi has the longest hind foot and $M$. mystacinus has the longest tail. The UPGMA trees were constructed for each sex, using skull and external measurements of Microtus specimens. As a result, $M$. dogramacii and $M$. guentheri being the most similar, and $M$. mystacinus is the sister species to these. But, it was determined that $M$. hartingi is distinctively from the these species.
\end{abstract}

Keywords: Microtus, Cricetidae, taxonomy, Turkey, morphometric

\section{Orta Anadolu Bölgesindeki Microtus Schrank, 1798 (Mammalia: Rodentia) Cinsine Ait Bazı Türlerin Morfometrik Karakteristiklerinin Karşılaştırılması \\ Öz}

Bu çalışmanın amacı Türkiye'nin Orta Anadolu bölgesinde bulunan Microtus türlerinin bazı morfometrik karakterlerini belirlemek ve karşılaştırmaktır. Bu çalışma 2003 ila 2010 yılları arasında Orta Anadolu'daki çeşitli yerlerden elde edilen 209 Microtus spp. örneğine dayanmaktadır. Türlerin taksonomik karakteristiklerini belirlemek için kürk rengi, kafatası özellikleri, diş morfotipleri ve baculum morfolojileri ile ilgili bazı özellikler kaydedilmiş ve değerlendirilmiştir. Çalışma alanında Microtus cinsine ait dört tür, Microtus dogramacii, Microtus guentheri, Microtus hartingi ve Microtus mystacinus tespit edilmiştir. Microtus hartingi Orta Anadolu bölgesinin genelinde yaygın olarak bulunmaktadır. M. guentheri tip yeri ve yakınındaki illerde tespit edilmiştir. Microtus guentheri ve $M$. hartingi simpatrik olarak bulunmamaktadır. Türler arasında $M$. hartingi en uzun ard ayak uzunluğuna ve $M$. mystacinus en uzun kuyruk uzunluğuna sahiptir. Her tür ve her eşey için kafatası ve dış ölçüler kullanılarak UPGMA ağacı oluşturulmuştur. Çalışmamız sonucunda $M$. dogramacii ve $M$. guentheri'nin birbirine en çok benzeyen türler olduğu, M. mystacinus'un bu türlere yakın olduğu ve $M$. hartingi'nin bu türlerden ayırt edici şekilde farklı olduğu görülmüştür.

Anahtar Sözcükler: Microtus, Cricetidae, taksonomi, Türkiye, morfometrik

\section{Introduction}

The genus Microtus represents one of the best known cases of rapid mammalian radiation resulting in about 65 extant species distributed throughout the Palearctic and Nearctic regions (Chaline et al., 1999; Jaarola et al., 2004). Turkey is 
rich in terms of the number of species, including some endemic ones. Several Microtus species were described as new species from Anatolia, including Microtus guentheri from Kahramanmaraş by Danford and Alston (1880), Microtus majori and Microtus roberti from Trabzon by Thomas (1906), Microtus pontius from Bayburt by Miller (1908), Microtus lydius from İzmir by Blackler (1916), Microtus dogramacii from Amasya by Kefelioğlu and Kryštufek (1999), M anatolicus from Konya by Kryštufek and Kefelioğlu (2001), and Microtus elbeyli from Kilis by Yiğit et al., (2016). Kryštufek and Vohralík (2005) gave distribution records in Anatolia of nine species of the genus Microtus, which they included in the subfamily Arvicolinae of the family Muridae. These species were divided into three main groups, including pine voles (subgenus Terricola), and arvalis and socialis groups (subgenus Microtus). M. subterraneus, $M$. daghestanicus, and $M$. majori were assigned to the pine vole group, $M$. rossiaemeridionalis, and $M$. obscurus were recorded in the arvalis group, and M. guentheri, $M$. anatolicus, $M$. dogramacii, and $M$. socialis were recorded in the socialis vole group. Musser and Carleton (2005) recorded the following Microtus species from Turkey: $M$. anatolicus, $M$. arvalis, $M$. daghestanicus, $M$. dogramacii, Microtus guentheri, $M$. socialis, $M$. subterraneus, M. majori, and M. levis. Selçuk et al., (2018) carried out a geometric morphometrics analysis of the skulls of $M$. anatolicus, $M$. dogramacii, M. guentheri, and M. levis. However, the taxonomic status and distribution of Microtus species in Asia Minor is still under discussion. The aim of this study is to determine some diagnostic morphological characteristics of Microtus species in the Central Anatolia region of Turkey.

\section{Material and Methods}

This study was based on 209 specimens belong to genus Microtus obtained between September 2003 and June 2010 in the Central
Anatolia region of Turkey. The study area is shown on the map in Figure 1. Specimens were obtained from live traps and snap traps. Following Thomas (1905), in addition to weight and four standard external measurements, 15 cranial and dental measurements were taken from each specimen using Vernier calipers. Specimens were preserved as conventional museum specimens following Mursaloğlu (1965). Fusion of the basisphenoid sutures, degree of tooth wear, fur colour, and field notes were used to define adulthood in species. Only adult specimens were used for morphological comparison and evaluation.

Determination of pelage coloration was made according to Ridgway (1886) and bacula was prepared according to Lidicker (1968). The occlusal patterns of molar teeth were evaluated following Niethammer and Krapp (1982). Variance analyses between the males and females specimens were made according to Parker (1979). Morphometric data were evaluated using the Rectangular Matrix prepared in the NTSYS-pc package program (ver 2.2). UPGMA (Unweighted Pair Group Method Using Aritmetric Averages), Maximum Parsimony and Maximum Likelihood trees were constructed using morphometric data used to determine morphological similarity of the species to each other (Swofford, 2002). In statistical analyses, $p \leq$ 0.05 was used as the significance level. For each measurement minimum and maximum values, arithmetic mean and standard deviations were calculated. The specimens are deposited at the Bolu Abant İzzet Baysal University, Agriculture and Natural Sciences Faculty, Wildlife Ecology and Management Department.

\section{Results}

Four species of Microtus were recorded in the study area, including $M$. dogramacii, $M$. guentheri, $M$. hartingi, and $M$. mystacinus. The distribution of Microtus specimens in the study area is shown in Figure 1. 


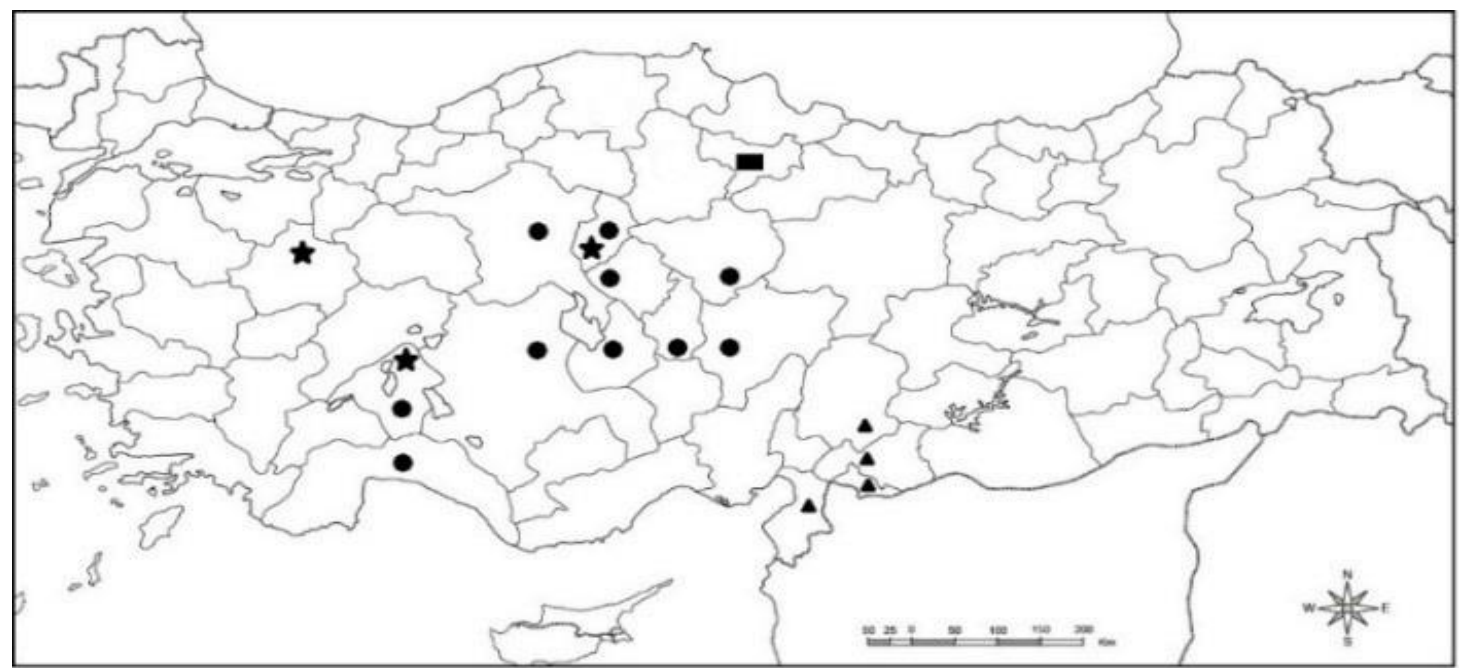

Figure 1. The Microtus specimens' localities in Central Anatolia ( $\square$ : M. dogramacii, $\triangle$ : M. guentheri, $\bigcirc$ : $M$. hartingi, to : M. mystacinus)

\section{Microtus dogramacii Kefelioğlu and Kryštufek,} 1999

The baculum length is $2.47-2.51 \mathrm{~mm}$ and the proximal width is $1.12-1.14 \mathrm{~mm}$. The proximal part of the baculum is triangular and has a rounded tip. The shaft narrows proximally to distally, slightly expanding near the distal part to form a knob shaped tip. The dorsal surface of the proximal part has a small pit and pronounced cupping ventrally with ridges at its borders (Figure 2). Skull has a light concavity from frontal to anterior at the interorbital region (Figure 3).
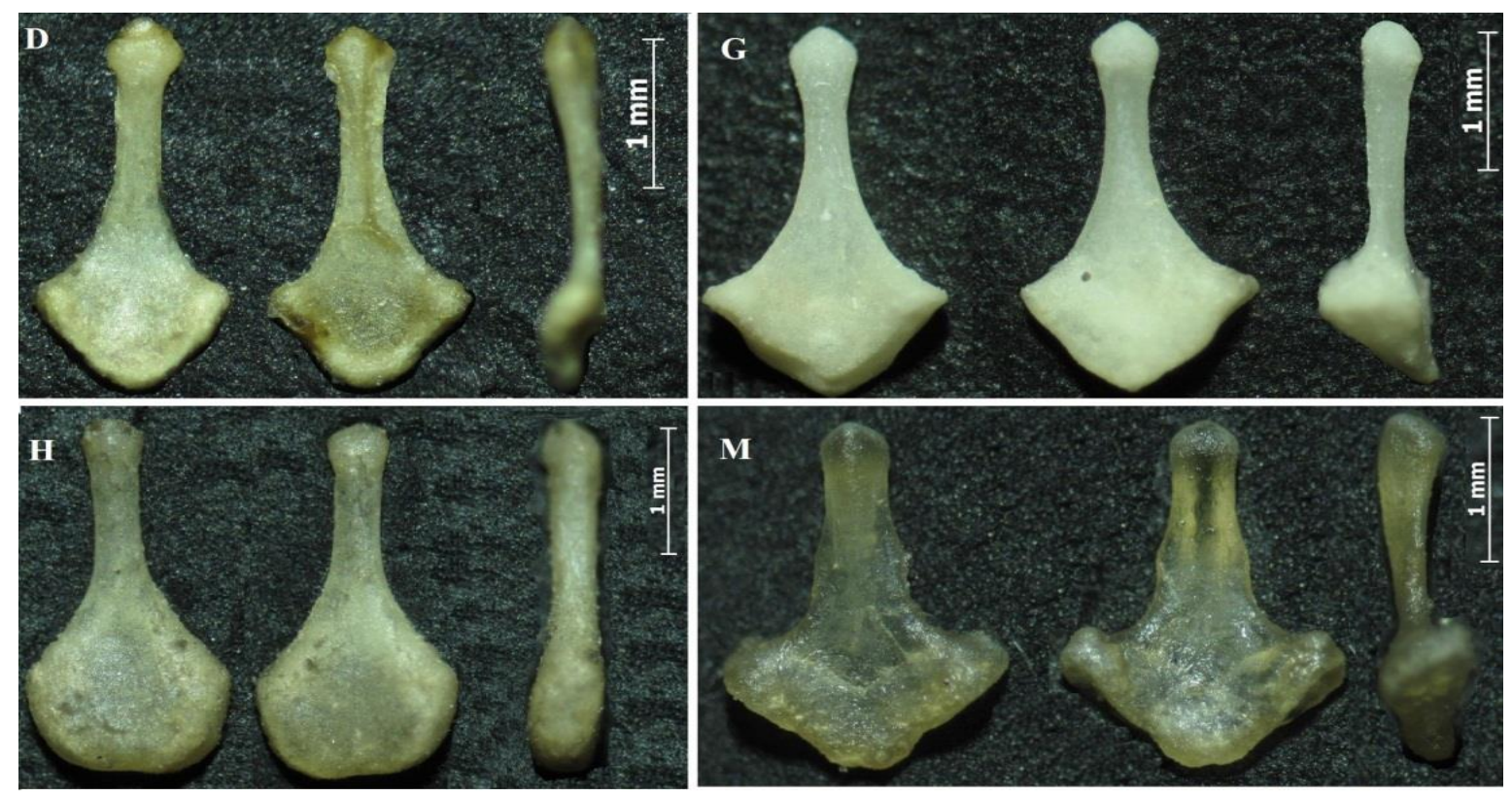

Figure 2. Bacula of Microtus species (D: M. dogramacii, G: M. guentheri, H: M. hartingi, M: M. mystacinus, from left to right: dorsal view, ventral view, and lateral view). 


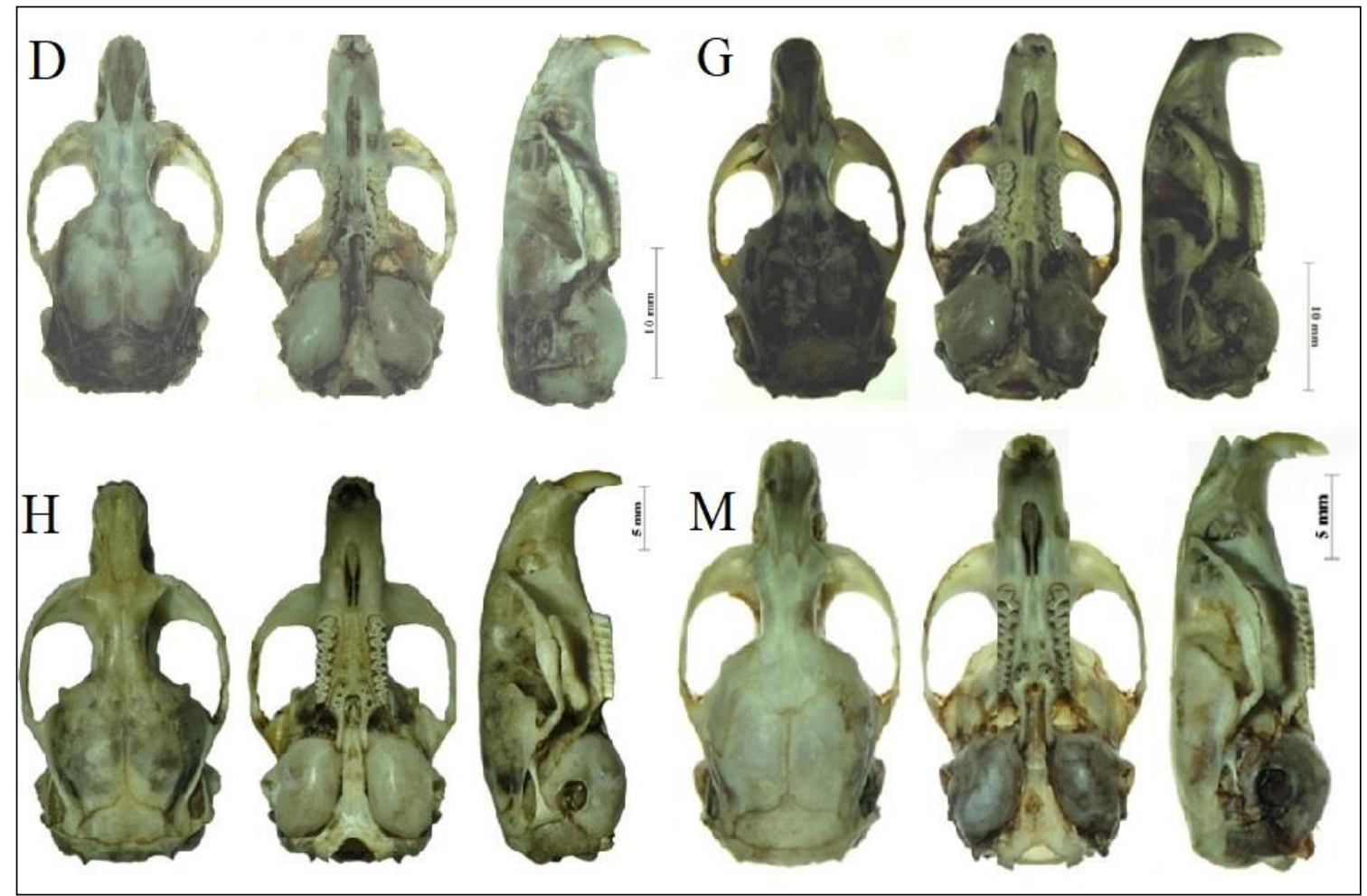

Figure 3. Skulls of Microtus species (D: M. dogramacii, G: M. guentheri, H: M. hartingi, M: M. mystacinus, from left to right: dorsal view, ventral view, and right lateral view)

In adult specimens, dorsal pelage coloration from the tip of the nose to the root of the tail is pale reddish light brown and the ventral colour is pale off-white. Tooth morphotypes of Microtus spp. and their percentages in our specimens are shown in Table 1.

Table 1. Morphotypes and percentages of $\mathrm{M}^{3}$ and $\mathrm{M}^{2}$ of Microtus species ( $\mathrm{M}^{3}$ : third upper molar, $\mathrm{M}^{2}$ : second upper molar)

\begin{tabular}{|c|c|c|c|c|c|c|}
\hline \multirow[t]{3}{*}{ Species } & \multicolumn{6}{|c|}{ Morphotypes } \\
\hline & \multicolumn{4}{|c|}{$\mathrm{M}^{3}$} & \multicolumn{2}{|c|}{$\mathrm{M}^{2}$} \\
\hline & Duplicata & Normal & Simplex & Complex & Agrestis & Non-Agrestis \\
\hline M. dogramacii & $67 \% n=4$ & $33 \% n=2$ & 0 & 0 & $100 \% n=6$ & 0 \\
\hline M. guentheri & $26 \% n=14$ & $69 \% n=37$ & $3.7 \% n=2$ & 0 & $92 \% n=49$ & $8 \% n=4$ \\
\hline M. hartingi & $27 \% n=60$ & $70 \% n=151$ & $1 \% n=3$ & $2 \% n=4$ & $98 \% n=215$ & $2 \% n=3$ \\
\hline M. mystacinus & $48 \% n=13$ & $52 \% n=14$ & 0 & 0 & $96 \% n=26$ & $4 \% n=1$ \\
\hline
\end{tabular}

External and skull measurements and body weights of adults of M. dogramacii are recorded in Table 2.

\section{Microtus guentheri (Danford and Alston, 1880)}

The baculum length is $2.69-2.75 \mathrm{~mm}$, the proximal width is $1.29-1.48 \mathrm{~mm}$ and the distal width is $0.42-0.44 \mathrm{~mm}$. The proximal part of the baculum is triangular and there is a depression in the median line along the length of the baculum. The tip of the distal part is pointed and looks like a knob (Figure 2). The dorsal profile of the skull is convex (Figure 3). In adult specimens, dorsal pelage coloration from the nose tip to the tail root is pale blackish brown. The ventral colour varies from pale greyish off white to slightly whitish grey. The dorsal and ventral colours merge gradually on the flanks. External and skull measurements and body weights of adult Microtus guentheri are recorded in Table 3. 
Table 2. Summary data of weight (g), external and cranial measurements $(\mathrm{mm})$ of adult Microtus dogramacii ( क्ष, \& \&) (n: number of individuals, r: range, m: mean, \pm Sd: standard deviation)

\begin{tabular}{lcccc}
\hline & Measurements & $\mathrm{n}$ & $\mathrm{m}$ & $\pm \mathrm{Sd}$ \\
\hline Head and body length & 3 & $101-118$ & 109.6 & 8.50 \\
Total length & 3 & $130-141$ & 136.6 & 5.85 \\
Tail length & 3 & $23-29$ & 27 & 3.46 \\
Hind foot length & 3 & $16-19$ & 17.6 & 1.52 \\
Ear length & 3 & $12-14$ & 13.3 & 1.15 \\
Weight & 3 & $39-46$ & 41.6 & 3.78 \\
Occipitonasal length & 2 & $25.8-27.2$ & 26.5 & 0.96 \\
Condylobasal length & 2 & $25.5-26.9$ & 26.2 & 0.97 \\
Palatal foramina length & 3 & $4.3-4.5$ & 4.4 & 0.13 \\
Palatal length & 3 & $12.6-13.5$ & 13.1 & 0.49 \\
Basilar length & 2 & $22.7-23.9$ & 23.3 & 0.84 \\
Nasal breadth & 3 & $2.7-3.0$ & 2.8 & 0.15 \\
Interorbital breadth & 3 & $3.7-4.1$ & 3.9 & 0.20 \\
Braincase breadth & 2 & $7.3-7.8$ & 7.5 & 0.31 \\
Zygomatic breadth & 3 & $15.0-16.1$ & 15.5 & 0.52 \\
Nasal length & 3 & $7-7.5$ & 7.3 & 0.30 \\
Diastema length & 3 & $7.2-8.1$ & 7.6 & 0.43 \\
Height of braincase & 2 & $10.2-10.5$ & 10.3 & 0.24 \\
Maxillary toothrow length & 3 & $5.6-6.1$ & 5.8 & 0.22 \\
Mandible length & 3 & $15.2-16.2$ & 15.7 & 0.53 \\
Mandible toothrow length & 3 & $5.6-6.1$ & 5.8 & 0.26 \\
Tail length /Head and body length (\%) & 3 & $19.4-28.7$ & 24.8 & 4.79 \\
\hline Six specimens were examined from Amasya
\end{tabular}

Six specimens were examined from Amasya: Boyalı village (4 fo of, 2 \& \&

Table 3. Summary data of weight $(\mathrm{g})$, external and cranial measurements $(\mathrm{mm})$ of adult Microtus guentheri

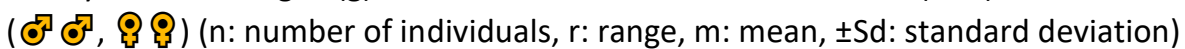

\begin{tabular}{lcccc}
\hline Measurements & $\mathrm{n}$ & $\mathrm{r}$ & $\mathrm{m}$ & \pm Sd \\
\hline Head and body length & 58 & $95-130$ & 106.1 & 7.12 \\
Total length & 58 & $116-165$ & 134.6 & 9.40 \\
Tail length & 58 & $21-39$ & 28.5 & 3.15 \\
Hind foot length & 58 & $13-20$ & 18.6 & 1.09 \\
Ear length & 58 & $11-19$ & 13.8 & 1.22 \\
Weight & 57 & $25-52.5$ & 33.4 & 5.74 \\
Occipitonasal length & 46 & $25.1-29.5$ & 27.1 & 1.05 \\
Condylobasal length & 47 & $24.8-29.6$ & 26.8 & 1.06 \\
Palatal foramina length & 58 & $3.9-5.5$ & 4.5 & 0.27 \\
Palatal length & 59 & $12.8-18$ & 13.8 & 0.76 \\
Basilar length & 46 & $22.5-26$ & 24.0 & 0.92 \\
Nasal breadth & 57 & $2.4-3.4$ & 2.9 & 0.21 \\
Interorbital breadth & 57 & $3.4-4$ & 3.7 & 0.13 \\
Braincase breadth & 45 & $5.2-7.2$ & 6.1 & 0.44 \\
Zygomatic breadth & 53 & $14.2-18.1$ & 15.4 & 0.79 \\
Nasal length & 57 & $6.2-9.1$ & 7.3 & 0.56 \\
Diastema length & 59 & $7.2-8.7$ & 7.9 & 0.34 \\
Height of braincase & 45 & $9.8-11.6$ & 10.6 & 0.37 \\
Maxillary toothrow length & 60 & $5.4-6.7$ & 6.1
\end{tabular}

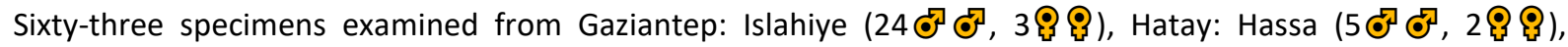

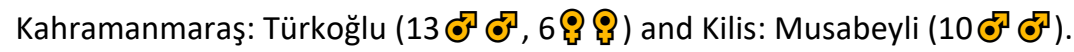




\section{Microtus hartingi Barrett-Hamilton, 1903}

The baculum length is $2.76-2.85 \mathrm{~mm}$ and the proximal width is $1.01-1.4 \mathrm{~mm}$. The proximal part of the baculum is oar-shaped and in a number of specimens, there is a slight recess in the middle of this part. From the proximal end to the middle of the baculum, the width decreases continuously and then it extends parallel to the distal tip. The distal tip is slightly pointed and knob-like. (Figure 2). The dorsal profile of the skull is slightly domed
(Figure 3). In adult specimens dorsal pelage coloration from the nose tip to the tail root is pale light brown. The ventral colour varies from light grey to yellowish off-white. The dorsal and ventral colours merge gradually on the flanks. External and skull measurements and body weights of adult Microtus hartingi are recorded in Table 4. Owing to statistical differences, measurements of the sexes are given separately (Table 4).

Table 4. Summary data of weight (g), external and cranial measurements ( $\mathrm{mm}$ ) of adult Microtus hartingi

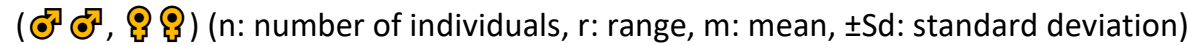

\begin{tabular}{|c|c|c|c|c|c|c|c|c|}
\hline \multirow[b]{2}{*}{ Measurements } & \multicolumn{4}{|c|}{ Male } & \multicolumn{4}{|c|}{ Female } \\
\hline & $\mathrm{n}$ & $r$ & $\mathrm{~m}$ & $\pm S d$ & $\mathrm{n}$ & $\mathrm{r}$ & $\mathrm{m}$ & $\pm \mathrm{Sd}$ \\
\hline Head and body length & 100 & $95-135$ & 112 & 8.98 & 63 & $96-135$ & 115.9 & 9.20 \\
\hline Total length & 100 & $125-170$ & 144.5 & 11.42 & 63 & $128-169$ & 147.8 & 10.09 \\
\hline Tail length & 100 & $24-45$ & 31.9 & 4.40 & 63 & $25-43$ & 31.9 & 3.79 \\
\hline Hind foot length & 100 & $20-24$ & 21.2 & 0.84 & 63 & $18-23$ & 20.8 & 1.05 \\
\hline Ear length & 98 & $11-16$ & 13.6 & 1.27 & 62 & $10-17$ & 13.2 & 1.58 \\
\hline Weight & 99 & $28-67$ & 43.6 & 9.11 & 63 & $23.5-89$ & 48.6 & 12.90 \\
\hline Occipitonasal length & 80 & $22-31.3$ & 28.5 & 1.58 & 54 & 25.4-31.5 & 28.9 & 1.34 \\
\hline Condylobasal length & 80 & $22-31$ & 28.1 & 1.51 & 55 & 24.9-31 & 28.4 & 1.42 \\
\hline Palatal foramina length & 103 & $3.7-10.1$ & 4.9 & 0.63 & 72 & $4-6.2$ & 4.9 & 0.43 \\
\hline Palatal length & 103 & $11.1-16$ & 14.4 & 0.78 & 72 & $12-16.6$ & 14.4 & 0.87 \\
\hline Basilar length & 80 & $19.4-27.8$ & 25.1 & 1.39 & 55 & $22-27.5$ & 25.4 & 1.28 \\
\hline Nasal breadth & 104 & 2.7-3.9 & 3.2 & 0.22 & 71 & $2.8-5.5$ & 3.3 & 0.33 \\
\hline Interorbital breadth & 97 & $3.5-4.1$ & 3.7 & 0.13 & 71 & $3.4-4$ & 3.7 & 0.12 \\
\hline Braincase breadth & 88 & $5.5-13.4$ & 8.8 & 3.06 & 61 & $5.2-13.5$ & 8.7 & 3.16 \\
\hline Zygomatic breadth & 92 & 13.1-19.7 & 16.5 & 1.12 & 62 & $13.8-18.8$ & 16.9 & 1.00 \\
\hline Nasal length & 103 & $6.6-9.3$ & 8.1 & 0.56 & 71 & $6.6-9.4$ & 8 & 0.59 \\
\hline Diastema length & 103 & $6-9.6$ & 8.4 & 0.56 & 72 & $6.9-9.6$ & 8.4 & 0.58 \\
\hline Height of braincase & 76 & $9.9-13$ & 11.4 & 0.50 & 49 & $9.5-12.2$ & 11.4 & 0.45 \\
\hline Maxillary toothrow length & 105 & $5.7-7.3$ & 6.4 & 0.35 & 73 & $5.7-7.1$ & 6.4 & 0.35 \\
\hline Mandible length & 104 & $13.8-19.2$ & 17.4 & 0.99 & 73 & $13.4-19.8$ & 17.4 & 1.14 \\
\hline Mandible toothrow length & 107 & $5.6-7.4$ & 6.3 & 0.39 & 73 & $5.7-7.1$ & 6.4 & 0.33 \\
\hline $\begin{array}{l}\text { Tail length/Head and body length } \\
\text { (\%) }\end{array}$ & 100 & $21-38.4$ & 28.4 & 3.63 & 63 & $20.8-38.3$ & 27.6 & 3.88 \\
\hline
\end{tabular}

One hundred and thirteen specimens were examined from Aksaray: Güzelyurt (7 fo of, 4 ६ ६ ), Yapılcan village (1\&), Ankara: Akyurt (1\%, 1\&),

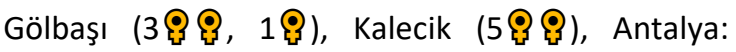

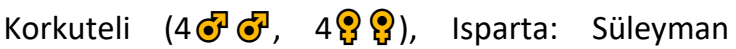
Demirel University Campus (1\&, 2 कా), Eğirdir (1\&), Keçiborlu (4\&) \& Kırıkkale: Delice (2 कా ), Tatlıcak village (4ळ大), Yahşihan: Kırıkkale University Campus (2 f) 1\&), Aşağımahmutlar village (1\&), Kırşehir: Kaman (2ळ్ఠ), Hamit

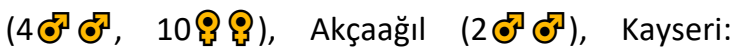
Yeşilhisar (1क्ष, 1\&), Konya: Bozkır (1 क्ष),

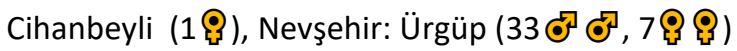
and Yozgat: Sorgun (1\%, $1 \&)$ ).

In this study, pelage coloration, cranial and external measurements and baculum morphology of the Microtus guentheri specimens from the type locality were found to be clearly different compared to specimens from the Central Anatolia region. M. lydius described by Blackler (1916) from İzmir and Microtus lydius ankaraensis described by 
Yiğit and Çolak (2002) from Ankara are similar to our specimens from Central Anatolia in terms of external and cranial morphometric measurements and baculum morphology. Moreover, M. lydius from İzmir with its longer tail and greyish-white abdomen has been demonstrated to be different from M. guentheri. However, $M$. lydius was accepted as a junior synonym of $M$. guentheri by Musser and Carleton (2005) and Kryštufek et al., (2010).

In this study it was concluded that the specimens from Central Anatolia are M. hartingi, the type locality for which is Larissa, Greece and which was described before $M$. lydius. Based on the priority rule, it was concluded that the name of the species should be $M$. hartingi. Kryštufek et al., (2009) constructed a phylogeny of social voles, using a sequence analysis of the mitochondrial cytochrome $b$ gene. This analysis showed that $M$. guentheri was composed of two allopatric sibling species, and $M$. guentheri was reported to have been distributed in Syria and Israel, whereas $M$. hartingi was distributed in the Balkans and Anatolia. This study also reported $M$. guentheri (west) samples from Anatolia, including Kırşehir, Antalya, Isparta, and from the Balkans, including Macedonia and Greece. In our study species differentiation was made by using external and skull measurements, pelage coloration and baculum morphology (Figure 3). Osborn's (1962) specimens of $M$. hartingi were similar to specimens from Thrace and Anatolia, so that these specimens may also belong to $M$. hartingi.

\section{Microtus mystacinus (de Filippe, 1865)}

The baculum length is $2.45-3.0 \mathrm{~mm}$ and the proximal width is $1.53-1.86 \mathrm{~mm}$. The proximal part of the baculum is triangular. The distal tip is somewhat rounded. The shaft is expanded laterally from about the middle of the shaft to the distal tip (Figure 2). Processes of interparietal bones extend through the interorbital region to back parts of nasals (Figure 3 ). In adults, dorsal pelage coloration from the nose tip to the tail root is light greyish brown and the ventral colour is light yellowish offwhite or greyish off-white. The dorsal and ventral colours merge gradually on the flanks. External and skull measurements and body weights of adult Microtus mystacinus are recorded in Table 5 . Owing to statistical differences, measurements for each sex are given separately (Table 5).

Twenty-seven specimens were examined from Isparta: Aksu, Yılanlı village (8क्ष, $7 \&$ \&

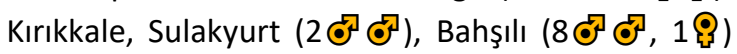
and Kütahya: Bölcek village (1 $\odot$ ).

Table 5. Summary data of weight (g), external and cranial measurements $(\mathrm{mm})$ of adult Microtus mystacinus (

\begin{tabular}{|c|c|c|c|c|c|c|c|c|}
\hline \multirow[b]{2}{*}{ Measurements } & \multicolumn{4}{|c|}{ Male } & \multicolumn{4}{|c|}{ Female } \\
\hline & $\mathrm{n}$ & $r$ & $\mathrm{~m}$ & $\pm S d$ & $\mathrm{n}$ & $r$ & $\mathrm{~m}$ & $\pm S d$ \\
\hline Head and body length & 14 & $96-121$ & 109 & 7.92 & 8 & $100-121$ & 108 & 6.85 \\
\hline Total length & 14 & $139-165$ & 153.5 & 9.21 & 8 & $142-165$ & 151.3 & 8.23 \\
\hline Tail length & 14 & $39-49$ & 44.5 & 3.08 & 8 & $39-47$ & 43.3 & 2.72 \\
\hline Hind foot length & 14 & $18-20$ & 19 & 0.83 & 8 & $17-20$ & 19 & 1.07 \\
\hline Ear length & 14 & $9-17$ & 13 & 1.84 & 8 & $9-16$ & 13.5 & 2.07 \\
\hline Weight & 14 & $25.5-46.5$ & 34 & 6.32 & 8 & $25-35$ & 29.6 & 3.53 \\
\hline Occipitonasal length & 15 & $24.7-28.1$ & 25.7 & 0.89 & 7 & $23.9-25.3$ & 24.7 & 0.43 \\
\hline Condylobasal length & 15 & $24.2-27.1$ & 25.3 & 0.78 & 7 & $23.5-25.5$ & 24.5 & 0.68 \\
\hline Palatal foramina length & 16 & $3.9-4.8$ & 4.2 & 0.28 & 8 & 3.9-4.6 & 4.3 & 0.25 \\
\hline Palatal length & 17 & $12.1-13.4$ & 12.7 & 0.34 & 8 & $12.1-12.9$ & 12.6 & 0.27 \\
\hline Basilar length & 15 & $21.1-24.3$ & 22.4 & 0.76 & 7 & $20.7-22.1$ & 21.6 & 0.49 \\
\hline Nasal breadth & 17 & $2.5-3.1$ & 2.9 & 0.15 & 8 & $2.6-3$ & 2.8 & 0.20 \\
\hline Interorbital breadth & 17 & $3.3-3.8$ & 3.6 & 0.12 & 8 & $3.2-3.8$ & 3.5 & 0.21 \\
\hline Braincase breadth & 15 & $5.7-11.9$ & 9.4 & 2.31 & 7 & $6.1-10.9$ & 7.6 & 2.10 \\
\hline Zygomatic breadth & 17 & $13.7-15.4$ & 14.3 & 0.55 & 7 & 13.6-14.6 & 14 & 0.33 \\
\hline Nasal length & 17 & $6.4-8.2$ & 7.2 & 0.59 & 8 & 6.5-7.3 & 6.9 & 0.33 \\
\hline Diastema length & 17 & $6.7-7.7$ & 7.1 & 0.28 & 8 & $6.6-7.2$ & 6.9 & 0.20 \\
\hline Height of braincase & 15 & $8.2-10.5$ & 9.7 & 0.55 & 7 & $9.4-9.8$ & 9.6 & 0.13 \\
\hline Maxillary toothrow length & 17 & $5.5-6.1$ & 5.7 & 0.15 & 8 & $5.5-6$ & 5.7 & 0.14 \\
\hline Mandible length & 17 & $14.4-16.1$ & 15.2 & 0.47 & 8 & 14.7-15.9 & 15.2 & 0.38 \\
\hline Mandible toothrow length & 17 & $5.4-6$ & 5.7 & 0.17 & 8 & 5.5-5.9 & 5.7 & 0.15 \\
\hline Tail length /Head and body length (\%) & 14 & $36.3-48.0$ & 40.9 & 3.63 & 8 & $36.3-45$ & 40.2 & 2.86 \\
\hline
\end{tabular}




\section{Discussion}

Numerous studies have been conducted in Anatolia to solve the complexity of the taxonomic status of the genus Microtus, resulting in a variety of often conflicting arrangements, e.g. [(Misonne (1957), Lehmann (1966), Çağlar (1967), Felten et al., (1971) Kurtonur (1975), Doğramacı (1989), Kefelioğlu (1995), Yiğit and Çolak (1998), Yiğit and Çolak (2002), Jaarola et al., (2004), Yiğit et al., (2006), Gözütok and Albayrak (2009), Yorulmaz et al., (2013), Arslan and Zima, 2014; Markov et al., 2014)]. This study has clarified the taxonomic status of Microtus spp, in Central Anatolia and provided diagnostic morphological characteristics to distinguish between the four identified species.

M. dogramacii was recorded from Aksaray and Konya except in the type locality (Jaarola et al., 2004). In this study, it was noted that $M$. dogramacii is similar to $M$. guentheri and the bacula of both are smaller than those of other species and have different morphologies. There are no differences between the external and cranial measurements and given by Kefelioğlu and Kryštufek (1999) and Kryštufek and Vohralík (2005) and those of our specimens from the type locality. However, Kryštufek and Vohralík (2005) recorded the Duplicata morphotype in $\mathrm{M}^{3}$ and the Agrestis morphotype in $\mathrm{M}^{2}$ in half of their specimens, whereas our specimens have Duplicata and Normal morphotypes in $\mathrm{M}^{3}$, and all have the Agrestis morphotype in $\mathrm{M}^{2}$.

Neuhäuser (1936) noted that $M . g$. guentheri was distributed in the provinces of Kahramanmaraş, Mersin, Ankara, Yozgat, Tokat, İstanbul, Sinop, Samsun, and $M$. g. lydius was recorded from the provinces of İzmir, Muğla, Afyon, Isparta, Kütahya, and Eskişehir. Ellerman (1948) recorded $M$. g. guentheri from Kahramanmaraş and $M$. $g$. Iydius from İzmir. Ellerman and Morrison-Scott (1951) accepted $M$. lydius as a subspecies of $M$. guentheri in their revision of mammals of the Palaearctic region.

Yiğit and Çolak (2002) recorded $M$. guentheri from Kahramanmaraş, Hatay, Gaziantep (Nizip), Kilis and M. Iydius from İzmir and Aydın. M. lydius ankaraensis was described as a new subspecies from Ankara, and distribution records of this subspecies were given from Ankara, Denizli, Kütahya, Eskisehir, Afyon, Burdur, Beysehir, Ankara, Kırıkkale and Kırşehir. M. guentheri differs from the other Microtus species from Central Anatolia in that it has the smallest ratio of tail length to head and body length and its baculum has a different shape. $M$. guentheri was described by Danford and Alston (1880) from Kahramanmaraş and hence our topotype specimens belong to the nominate subspecies $M$. g. guentheri, which was confirmed by comparison skull measurements, and non-metric characters (tail features, pelage coloration and number of plantar tubercles on the hind feet). No differences were found when compared with the data for $M$. g. guentheri given by Kefelioğlu (1995), Çolak et al., (1997) and Yiğit and Çolak (2002). The specimens taken from Kahramanmaraş and Mersin by Danford and Alston (1880) and Kefelioğlu (1995) were also included in $M$. g. guentheri. Our $M$. guentheri specimens from Kahramanmaraş, Gaziantep, Kilis, and Hatay differ in terms of smaller body size, pelage coloration, and baculum morphology from M. hartingi in Central Anatolia. Microtus guentheri has often been recorded by other authors from Central Anatolia, but these specimens may actually belong to $M$. hartingi.

M. I. ankaraensis was described by Yiğit and Çolak (2002) and differs from M. g. guentheri. $M$. lydius is actually a junior synonym of $M$. hartingi. Therefore $M$. I. ankaraensis should also belong to this species, which is confirmed from distributional records, baculum morphology and external and skull morphometric data.

The data for M. g. hartingi given by Ondrias (1965) are consistent with our samples and these specimens were found to be on average larger than ours. There are no differences between the measurements of our specimens of $M$. g. guentheri and those of Ondrias (1965). Similarly, there are also no differences between the external and skull morphometric measurements and baculum morphology of our $M$. guentheri specimens and those of Çolak et al., (1997). Yiğit et al., (2012) examined the phenotypic characteristics of the Guentheri group. These authors recorded that the non-agrestis morphotype was found in $\mathrm{M}^{2}$ in all specimens of $M$. guentheri from Bulgaria, Turkish Thrace and Western Anatolia and Normal, Simplex, Duplicata and Complex morphotypes were found in $\mathrm{M}^{3}$. Consequently, they recorded that specimens from Bulgaria and Turkish Thrace could not be identified as $M$. guentheri and specimens from Western Anatolia should be $M$. lydius (=M. hartingi). In our $M$. guentheri specimens $92 \%$ $(n=49)$ have the non-Agrestis morphotype for $M^{2}$ and $8 \%(n=4)$ have Agrestis morphotypes. For $M^{3}$, $26 \%(n=14)$ have the Duplicata morphotype, 69\% $(n=37)$ the Normal morphotype, and $3.7 \%(n=2)$ the Simplex morphotype in our $M$. guentheri specimens. In contrast, $\mathrm{M}^{3}$ in our $M$. hartingi specimens from the Middle Anatolia Region have 27\% ( $n=60)$ Duplicata morphotype, 70\% ( $n=151)$ Normal morphotype, $1 \% \quad(n=3) \quad$ Simplex morphotypes and $2 \%(n=4)$ Complex morphotype. 
In addition, the baculum morphology of M. lydius, reported by Yiğit et al., (2012), is similar to that of our $M$. hartingi specimens.

Markov et al., (2014) analysed 32 qualitative non-metric skull characters in M. lydius lydius, M. I. ankarensis, $M$. guentheri guentheri, and $M$. hartingi strandzensis from Anatolia and the Balkan Peninsula. Based on these skull characters, the highest degree of similarity was found between $M$. I. Iydius and M. I. ankarensis. M. g. guentheri was closer to $M$. $h$. strandzensis than to $M$. I. Iydius and M. I. ankarensis. In our study, $M$. hartingi and $M$. guentheri are easily distinguishable based on statistical analysis of external and skull morphometric measurements.

Although Selçuk et al., (2018) noted that $M$. guentheri has the largest skull, condylobasal length and occipitonasal length were larger in our specimens of $M$. hartingi.

Our M. mystacinus specimens differ from other Microtus species in that they have the longest tails (36-48\% of the head and body length), six plantar tubercles on the hind foot, and the interparietal processes extend through the interorbital region to posterior of the nasals. Synonyms of $M$. mystacinus include $M$. subarvalis
Meyer, Orlov \& Skholl, 1969, M. epiroticus Ondrias, 1966, M. rossiaemeridionalis Ognev, 1924, and $M$. levis Miller, 1908 (Mahmoudi et al., 2014; 2017).

No differences were observed between the data for $M$. epiroticus given by Kefelioğlu (1995) and our data for M. mystacinus. However, the measurements given by other researchers could not be compared for $M$. arvalis and $M$. levis, because these specimens were not reliably identified using karyological data. There are no differences between the external and skull measurements and diagnostic characters of our specimens of M. levis and those of Ognev (1964), Mažeikytè et al., (1999), Massing (1999), Kefelioğlu, (1995).

Selçuk et al., (2018) reported that there was no sexual dimorphism in $M$. levis based on multivariate analysis of external and skull morphometrics, but inter-sexual differences were found in our specimens from skull measurements. In our study based on average values, $M$. mystacinus has the shortest conylobasal length and occipitonasal length. $M$. hartingi has the longest hind foot length and M. mystacinus has the longest tail length in our study (Figure 4; Figure 5).

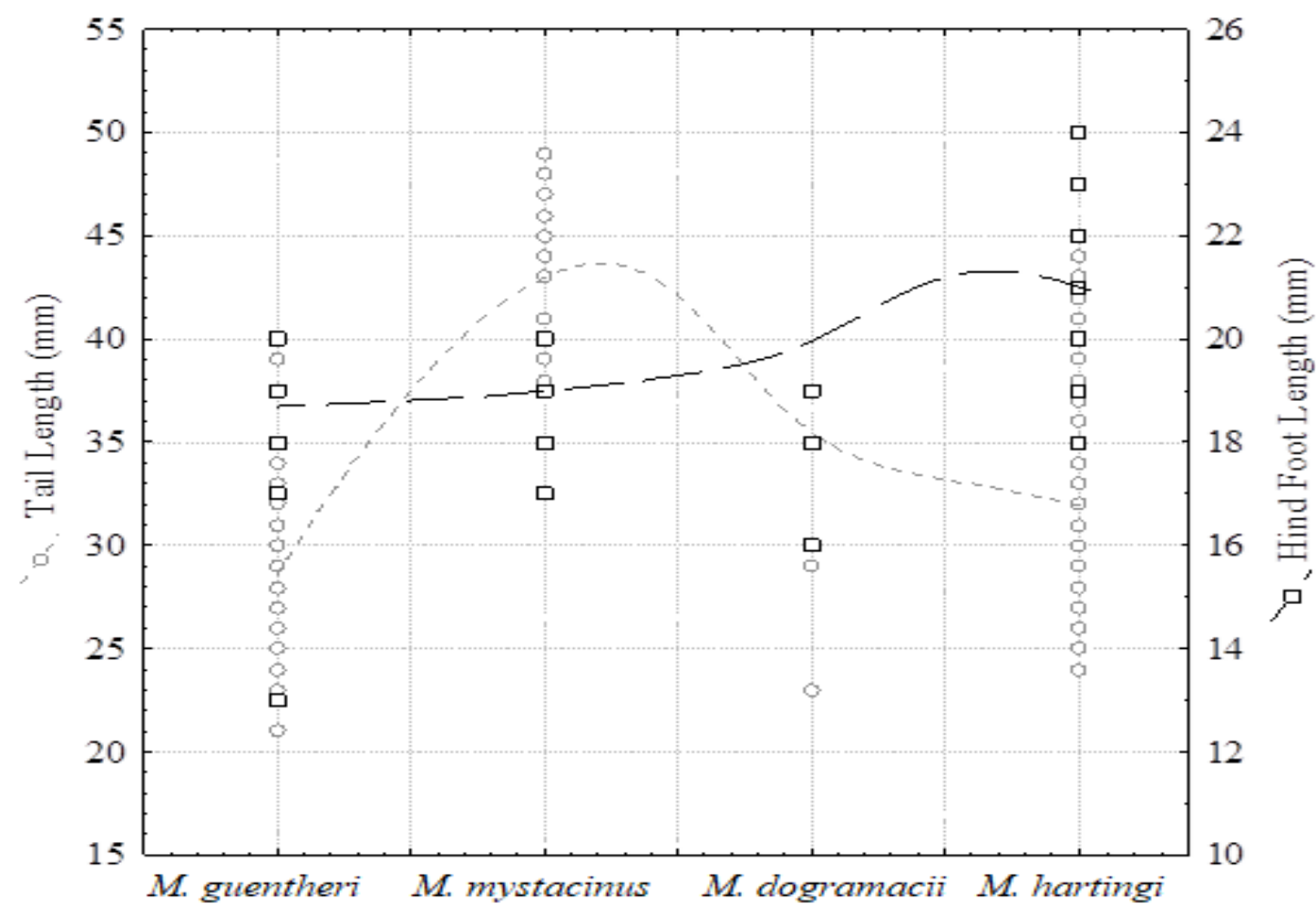

Figure 4. Scatterplot of hind foot length against tail length (in $\mathrm{mm}$ ) of Microtus species from Central Anatolia 


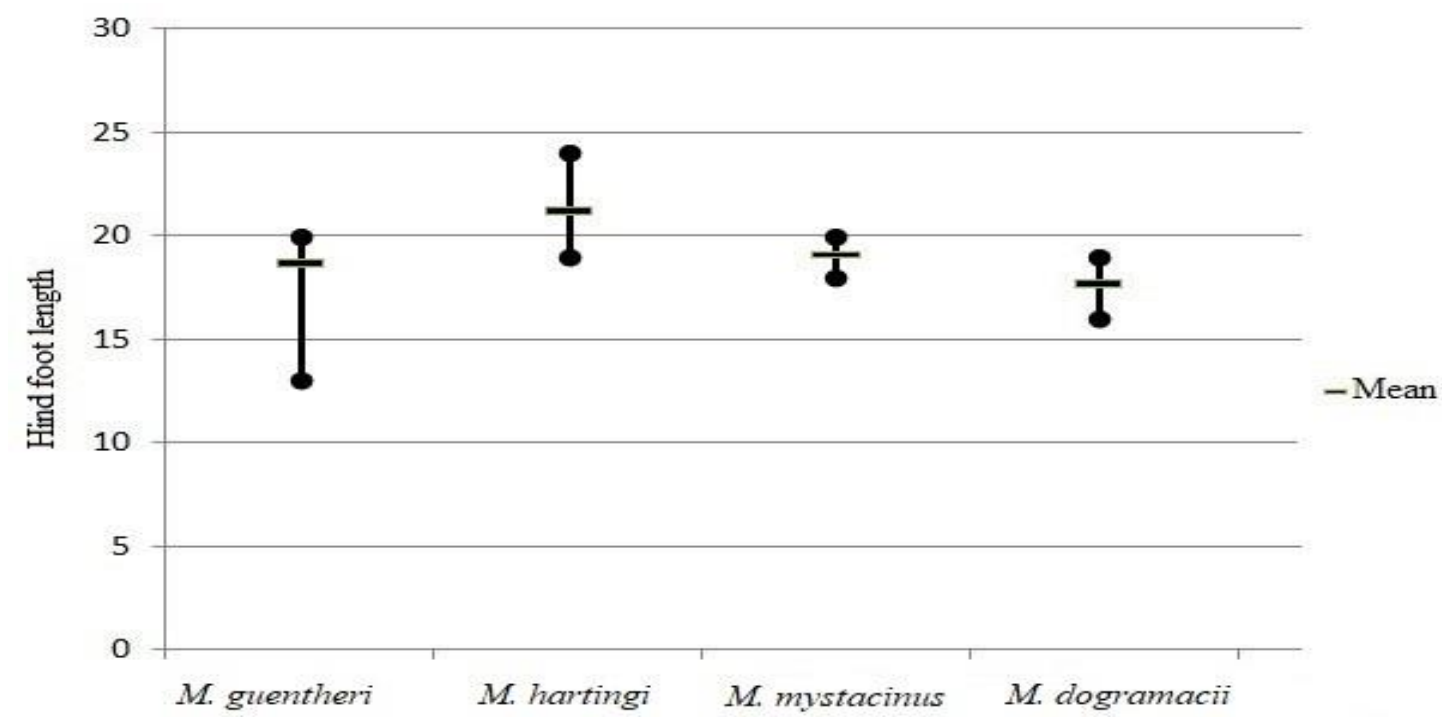

Figure 5. Comparison of hind foot lengths (in $\mathrm{mm}$ ) of Microtus species from Central Anatolia

The UPGMA trees constructed for each sex, using skull and external measurements of specimens belonging to the genus Microtus from the Central Anatolia Region of Turkey, are shown in Figure 6.
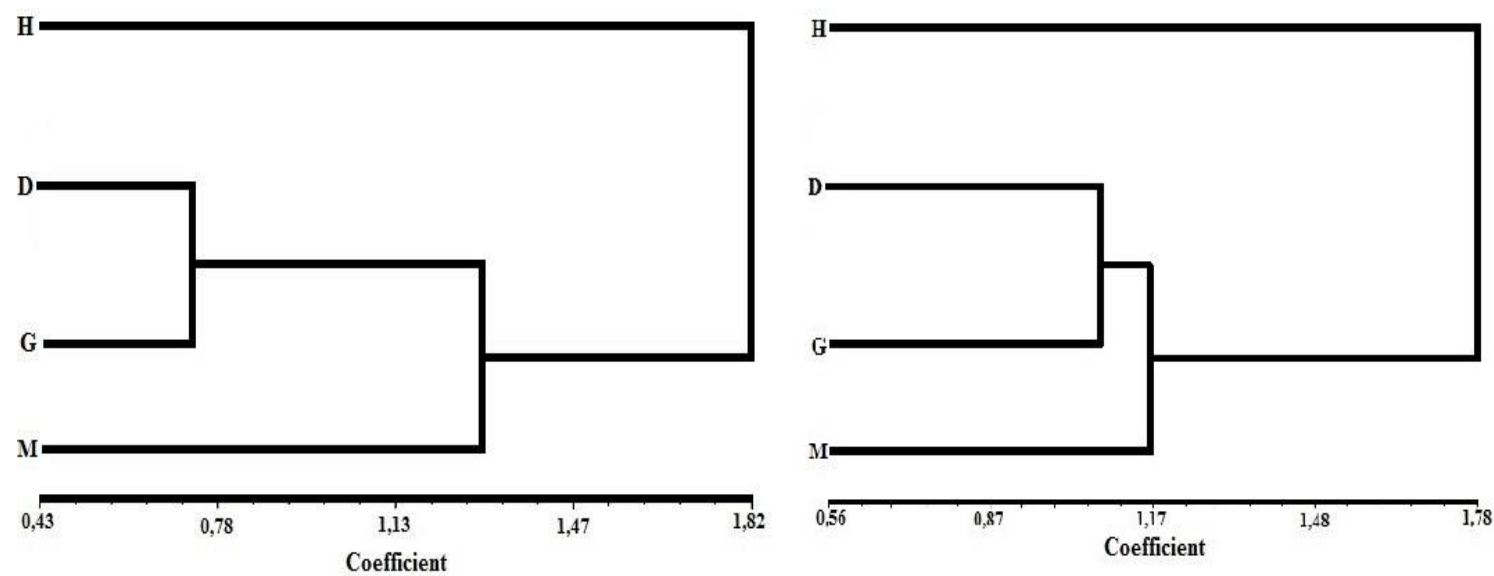

Figure 6. UPGMA tree constructed using morphometric characteristics of male specimens (left) and female specimens (right) of Microtus species ( $\mathrm{H}:$ M. hartingi, G: M. guentheri, M: M. mystacinus, D: M. dogramacii) Each sex shows a similar pattern of morphological similarity between species, with $M$. dogramacii and $M$. guentheri being the most similar, $M$. mystacinus is the sister species to these and $M$. hartingi is the most distinctively different.

\section{Acknowledgement}

We thank Dr. A. C. Kitchener for reading the entire manuscript in its original form. This study was a part of the Ph. D. thesis of Serdar Gözütok.

\section{References}

Arslan, A., and Zima, J. 2014. Karyotypes of the mammals of Turkey and neighbouring regions: A review. Folia Zoologica, 63 (1): 162.

Blackler, W.F.G. 1916. On a new species of Microtus from Asia Minor. The Annals and
Magazine of Natural History; Zoology, Botany, and Geology, ${ }^{\text {th }}$ ser (17): 426-427.

Chaline, J., Brunet-Lecomte, P., Montuire, S., Viriot, L., and Courant, F. 1999. Anatomy of the arvicoline radiation (Rodentia): Palaeogeographical, palaeoecological history and evolutionary data. Annales Zoologici Fennici, 36: 239-267.

Çağlar, M. 1967. Türkiye'nin Gömülgen Fareleri (Microtin). Türk Bioloji Dergisi, 17: 103-117.

Çolak, E., Yiğit, N., Sözen, M., and Özkurt, Ş. 1997. Distribution and taxonomic status of the 
genus Microtus (Mammalia: Rodentia) in Southern Turkey. Israel Journal of Zoology, 43 (4): 391-396.

Danford, C.G., and Alston, E.R. 1880. On the Mammals of Asia Minor. Part II. Proceedings of the Zoological Society of London, 50-64.

Doğramacı, S. 1989. Türkiye Memeli Faunası. Ondokuz Mayıs Üniversitesi Fen Dergisi 1(3): 107-136.

Ellerman, J.R. 1948. Key to the Rodents of SouthWest Asia in the British Museum Collection. Proceedings of the Zoological Society of London, 118 (3): 765-816.

Ellerman, J. R., and Morrison-Scott, T.C.S. 1951. Checklist of Palaearctic and Indian Mammals 1758-1946. London: British Museum (Natural History). Department of Zoology, 1-810.

Felten, H., Spitzenberger, F., and Storch, G. 1971. Zur Kleinsäugerfauna West Anatoliens. Teil I, Senckerbergiana Biologica 52(6): 393-424.

Gözütok, S., and Albayrak, İ. 2009. Biology and ecology of the species of the Genus Microtus (Schrank, 1798) in Kırıkkale province (Mammalia: Rodentia). International Journal of Natural and Engineering Sciences 3 (3): 94-101.

Jaarola, M., Martinkova, N., Gunduz, I., Brunhoff, C., Zima, J., Nadachowski, A., Amori, G., Bulatova, N., Chondropoulos, B., Fraguedakis-Tsolis, S., Gonzalez-E., Jorge López-Fuster, M., Kandaurov, A., Kefelioğlu, H., Mathias, M. L., Villate, I., and Searle, J. 2004. Molecular phylogeny of the speciose vole genus Microtus (Arvicolinae, Rodentia) inferred from mitochondrial DNA sequences. Molecular Phylogenetics and Evolution, 33 (3): 647-663.

Kefelioğlu, H., 1995. The taxonomy of the genus of Microtus (Mammalia: Rodentia) and its distribution in Turkey. Turkish Journal of Zoology, 19: 35-63.

Kefelioğlu, H., and Kryštufek, B. 1999. The taxonomy of Microtus socialis group (Rodentia: Microtinae) in Turkey, with the description of a new species. Journal of Natural History, 3: 289-303.

Kryštufek, B., and Kefelioğlu, H. 2001. Redescription and species limits of Microtus irani, Thomas, 1921, and description of a new social vole from Turkey (Mammalia: Arvicolinae). Bonner Zoologische Beiträge: Herausgeber: Zoologisches Forschungsinstitut und Museum Alexander Koenig Bonn, 50 (1-2): 1-14.

Kryštufek, B., and Vohralík, V. 2005. Mammals of
Turkey and Cyprus Rodentia I: Sciuridae, Dipodidae, Gliridae, Arvicolinae. Koper Slovenia: University of Primorska Science and Research, 1-292.

Kryštufek, B., Bužan, E. V., Vohralik, V., Zareie, R., and Özkan, B. 2009. Mitochondrial cytochrome b sequence yields new insight into the speciation of social voles in southwest Asia. Biological Journal of the Linnean Society, 98: 121-128.

Kryštufek, B., Vohralik, V., Zima, J., Koubínová, D., and Bužan, E.V. 2010. A new subspecies of the Iranian Vole, Microtus irani Thomas, 1921, from Turkey (Mammalia: Rodentia). Zoology in the Middle East, 50 (1): 11-18.

Kurtonur, C. 1975. New records of Thracian Mammals. Saugetierkunde Mitt, 23: 14-16.

Lehmann, E. 1966. Taxonomische bemerkungen zur Saegerausbeute der Kummerloeve'schen Orientreisen 19531965. Zoologie Beitrage 12: 251-317.

Lidicker, W.Z. 1968. A phylogeny of New Guinea rodent genera based on phallic morphology. Journal of Mammalogy, 49 (4): 609-643.

Mahmoudi, A., Darvish, J., Aliabadian, M., Khosravi, M., Golenishchev, F., and Kryštufek, B. 2014. Chromosomal diversity in the genus Microtus at its southern distributional margin in Iran. Folia Zoologica Praha, 4: 290-295.

Mahmoudi, A., Kryštufek, B., Darvish, J., Aliabadian, M., Tabatabaei Yazdi, F., Yazdani Moghaddam, F., and Janžekovič, F. 2017. Craniometrics are not outdated: Interspecific morphological divergence in cryptic arvicoline rodents from Iran. Zoologischer Anzeiger. A Journal of Comparative Zoology, 270. 9-18.

Markov, G., Yiğit, N., Çolak, E., Kocheva, M., and Gospodinova, M. 2014. Epigenetic diversity and similarity of the voles of "Guentheri" group (Mammalia: Rodentia) in Anatolian Peninsula and South-Eastern part of the Balkan Peninsula. Acta Zoologica Bulgarica, 66: 159-164.

Mažeikytė, R., Baranauskas, K., Morkūnas, V., and Mickevičius, E. 1999. Distribution of the sibling vole (Microtus rossiaemeridionalis Ognev, 1924) (Rodentia, Cricetidae) in Lithuania. Acta Zoologica Lituanica, 9 (1): 315.

Massing, M. 1999. The skull of Microtus levis (Arvicolidae, Rodentia). Folia Theriologica Estonica, 4: 76-90.

Miller, G.S. 1908. The recent voles of the Microtus nivalis group. (Microtus pontius sp. $\mathrm{n}$ ). The 
Annals and Magazine of Natural History; Zoology, Botany, and Geology 1: 102-103.

Misonne, X. 1957. Mammiferes de la Turquie SudOrientale et du nord de La Syrie. Mammalia, 21: 53-67.

Musser, G.G., and Carleton, M.D. 2005. Family: Cricetidae. In: Wilson DE, Reeder DM (editors). Mammals Species of the World A Taxonomic and Geographic Reference. Third ed. Baltimore: Johns Hopkins University Press, pp. 955-1189.

Mursaloğlu, B. 1965. Bilimsel Araştırmalar için Omurgalı Numunelerinin Toplanması ve Hazırlanması. Ankara: Ankara Üniversitesi Fen Fakültesi Yayınları Basımevi.

Neuhäuser, G. 1936. Die Muriden von Kleinasien. Zeitschrift für Säugetierkunde, 11: 161-236.

Niethammer, J., and Krapp, F. 1982. Handbuch der Säugetiere Europas. Bd. 2/I. Rodentia II (Cricetidae, Arvicolidae, Zapodidae, Spalacidae, Hystricidae, Capromyidae). Wiesbaden: Akademische Verlagsgesellschaft, 1-640.

Ognev, S.L. 1964. Mammals of U.S.S.R. and adjacent countries (Rodents). Jerusalem: Israel program for scientific translations, 1508.

Ondrias, J. 1965. Contribution to the knowledge of Microtus guentheri hartingi from Thebes, Greece. Mammalia, 29 (4): 489-506.

Osborn, D.J. 1962. Rodents of the Subfamily Microtinae from Turkey. Journal of Mammalogy, 43: 515-529.

Parker, R.E. 1979. Introductory Statistics for Biology. London: Cambridge University Press, 1-222.

Ridgway, R. 1886. A nomenclature of colours for naturalists and compendium of useful knowledge for ornithologists. Boston: Little, Brown and Company, 1-129.

Selçuk, A.Y., Kaya, A, and Kefelioğlu, H. 2018. Geomorphometric differences among four species of Microtus in Turkey (Mammalia: Rodentia). Zoology in the Middle East 64 (1): 1-11.

Swofford, D.L. 2002. PAUP: Phylogenetic analysis using parsimony (* and other methods) ver 4. Massachusetts: Sinauer Associates Sunderland.

Thomas, O. 1905. Suggestions for the Nomenclature of the Cranial Length Measurement and of the Cheek-Teeth of Mammals. Proceedings of the Zoological Society of London, 18: 191-196.

Thomas, O. 1906. On new Insectivores and Voles. The Annals and Magazine of Natural
History, 17: 415-421.

Yiğit, N., and Çolak, E. 1998. Contribution to the geographic distribution of rodent species and ecological analyses of their habitats in Asiatic Turkey. Turkish Journal of Zoology, 22: 435-446.

Yiğit, N., and Çolak, E. 2002. On the distribution and taxonomic status of Microtus guentheri (Danford and Alston, 1880) and Microtus lydius Blackler,1916 (Mammalia: Rodentia) in Turkey. Turkish Journal of Zoology, 26: 197-204.

Yiğit, N., Gharkheloo, M.M., Çolak, E., Özkurt, Ş., Bulut, S., Kankılıç, T., and Çolak, R. 2006. The karyotypes of some species (Mammalia: Rodentia) from Eastern Turkey and Northern Iran with a new record, Microtus schidlovskii Argyropulo, 1933, from Eastern Turkey. Turkish Journal of Zoology, 30: 459464.

Yigit, N., Markov, G., Colak, E., Kocheva, M., Saygili, F., Yuce, D., and Cam, P. 2012. Phenotypic features of the "guentheri" group Vole (Mammalia: Rodentia) in Turkey and Southeast Bulgaria: evidence for its taxonomic detachment. Acta Zoologica Bulgarica, 64 (1): 23-32.

Yiğit, N., Çolak, E., and Sözen, M. 2016. A new species of voles, Microtus elbeyli sp. nov., from Turkey with taxonomic overview of social voles distributed in southeastern Anatolia. Turkish Journal of Zoology, 40: 7379.

Yorulmaz, T., Zima, J., Arslan, A., and Kankiliç. T. 2013. Variations in C-heterochromatin and AgNOR distribution in the common vole (Microtus arvalis sensu lato) (Mammalia: Rodentia). Arch. Biol. Sci., 65: 989-995.

Zima, J., Červený, J., Hrabĕ, V., Král, B., and Šebela, M. 1981. On the occurence of Microtus epiroticus in Rumania (Arvicolidae, Rodentia). Folia Zoologica, 30 (2): 139-146. 